\title{
Assessment of Strippable Coatings for Decontamination and Decommissioning
}

\author{
Topical Report \\ January 1998
}

\author{
By: \\ M. A. Ebadian
}

Work Performed Under Contract No.: DE-FG21-95EW55094

For

U.S. Department of Energy

Office of Fossil Energy

Federal Energy Technology Center

P.O. Box 880

Morgantown, West Virginia 26507-0880
RECEIVED

OCT 201998

OSTI

By

Florida International University

Hemispheric Center for Environmental Technology (HCET)

Center for Engineering \& Applied Sciences

10555 West Flagler Street

EAS-2100

Miami, Florida 33174 


\section{Disclaimer}

This report was prepared as an account of work sponsored by an agency of the United States Government. Neither the United States Government nor any agency thereof, nor any of their employees, makes any warranty, express or implied, or assumes any legal liability or responsibility for the accuracy, completeness, or usefulness of any information, apparatus, product, or process disclosed, or represents that its use would not infringe privately owed rights. Reference herein to any specific commercial product, process, or service by trade name, trademark, manufacturer, or otherwise does not necessarily constitute or imply its endorsement, recommendation, or favoring by the United States Government or any agency thereof. The views and opinions of authors expressed herein do not necessarily state or reflect those of the United States Government or any agency thereof. 


\section{DISCLAIMER}

Portions of this document may be illegible electronic image products. Images are produced from the best available original document. 


\section{ACKNOWLEDGMENTS}

This report is based on work supported by the U.S. Department of Energy, Office of Environmental Management, Office of Science and Technology's Deactivation and Decommissioning Focus Area, Morgantown Energy Technology Center. The Principal Investigator, Florida International University Collaborator, and students at Florida International University would like to thank Dr. Paul Hart for providing us the opportunity to work on this project. 
ACRONYMS

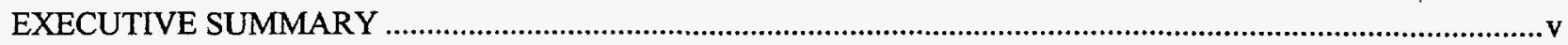

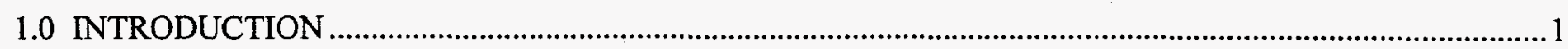

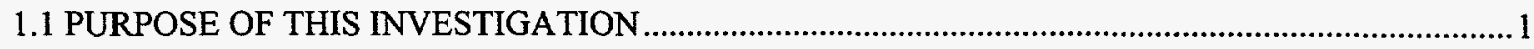

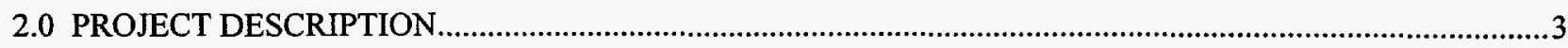

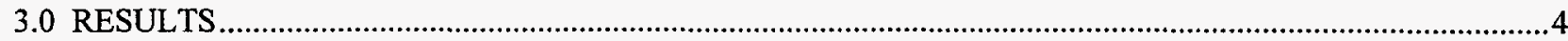

3.1 IDENTIFICATION OF COMMERCIALLY AVAILABLE STRIPPABLE

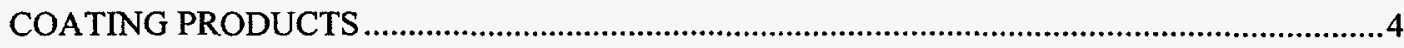

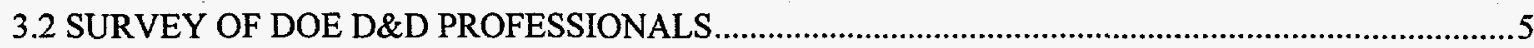

3.3 DESIGN OF NON-RADIOLOGICAL LABORATORY-SCALE TESTING OF

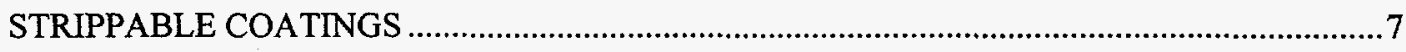

3.3.1 Use of the Super Nova SP Spray Applicator .......................................................................

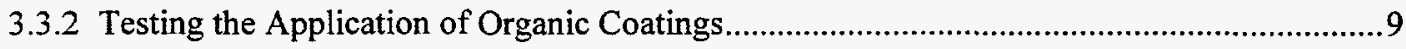

3.3.3 Application and Removal of Strippable Coatings on Difficult Materials ............................. 10

3.3.4 Conducting Accelerated Outdoor Exposure Testing of Organic Coatings ........................... 10

3.3.5 Measuring Abrasion Resistance of Organic Coatings......................................................... 11

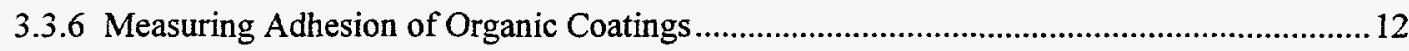

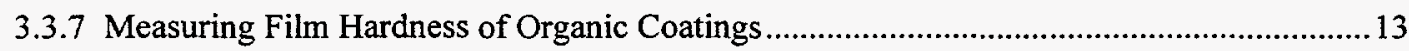

3.3.8 Measuring Tensile Strength of Organic Coatings .............................................................. 13

3.3.9 Determination of Decontamination Factors for Strippable Coatings ....................................13

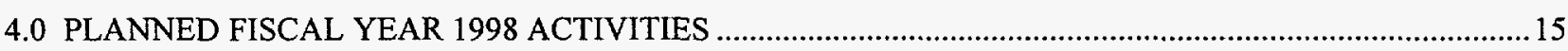

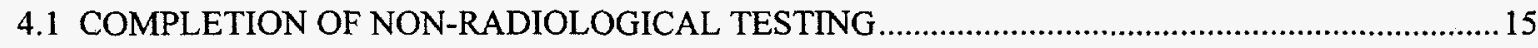

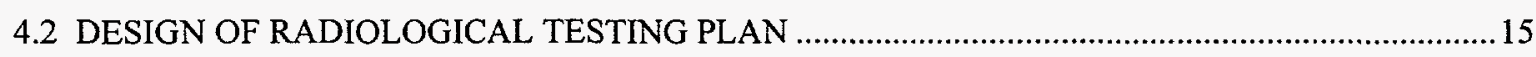

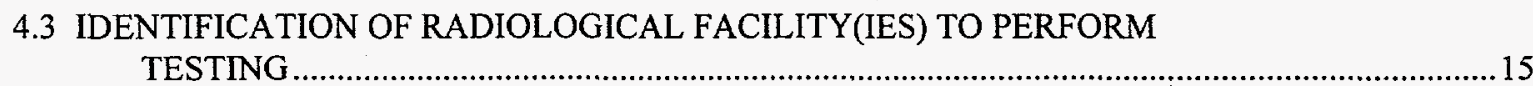

4.4 RADIOLOGICAL TESTING OF TARGETED STRIPPABLE COATING

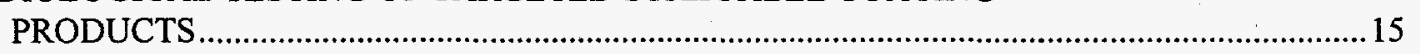

4.5 NON-RADIOLOGICAL TESTING OF NEWLY IDENTIFIED STRIPPABLE

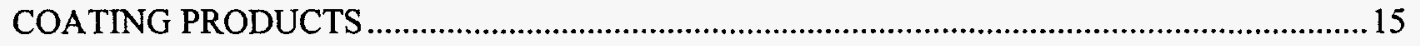

4.6 GENERATION AND POPULATION OF MULTIMEDIA INFORMATION

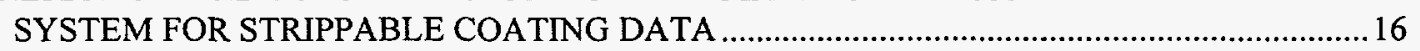

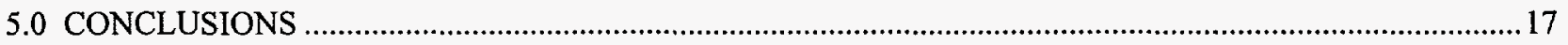

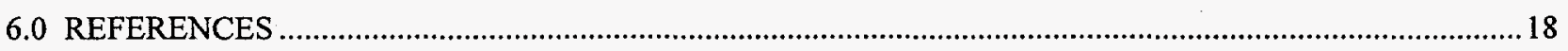

APPENDIX A

APPENDIX B

APPENDIX C

APPENDIX D 


\section{ACRONYMS}

ASTM

CMU

D\&D

DF

DOE

FIU

FY97

FY98

HCET

INEL

LANL

MISD

MSDS

ORNL

RAPIC

SEM

SIMCON

STCG

TMI

XRF
American Society for Testing and Materials

concrete masonry units

decontamination and decommissioning

decontamination factor

U.S. Department of Energy

Florida International University

fiscal year 1997

fiscal year 1998

Hemispheric Center for Environmental Technology

Idaho National Engineering Laboratory

Los Alamos National Laboratory

multimedia information system for decontamination

material safety data sheet

Oak Ridge National Laboratory

Remedial Action Program Information Center

scanning electron microscopy

simulated contamination

site technology coordination group

Three Mile Island

$\mathrm{x}$-ray fluorescence 
Strippable or temporary coatings were developed to assist in the decontamination of the Three Mile Island (TMI-2) reactor. These coatings have become a viable option during the decontamination and decommissioning (D\&D) of both U.S. Department of Energy (DOE) and commercial nuclear facilities to remove or fix loose contamination on both vertical and horizontal surfaces. A variety of strippable coatings are available to D\&D professionals. However, these products exhibit a wide range of performance criteria and uses. For instance, some strippable coatings were designed to protect spray paint booths or small tools only, while others can be used for decontaminating or fixing loose contamination on floors and walls. As a result of the lack of comprehensive and comparable performance data regarding these products, D\&D professionals tend to make decisions using limited information.

The Hemispheric Center for Environmental Technology (HCET) at Florida International University (FIU) was commissioned to perform a 2-year investigation into strippable coatings. This investigation was divided into four parts: (1) identification of commercially available strippable coating products; (2) survey of D\&D professionals to determine current uses of these coatings and performance criteria; (3) design and implementation of a non-radiological testing program to evaluate the physical properties of these coatings; and (4) design and implementation of a radiological testing program to determine decontamination factors and effects of exposure to ionizing radiation.

During fiscal year 1997 (FY97), the following activities were completed:

- Information about strippable coating products was requested from over 30 companies. Nineteen responses were received with six of these companies selling products that could be used for radiological decontamination.

- D\&D professionals were surveyed about current and future uses of strippable coatings as well as performance criteria to be considered when choosing a product. Over 20 surveys were distributed across the DOE Complex, and seven of these facilities provided responses. Performance criteria ranged from a need for the product to be strong and pliable to needs for the product to be non-organic based and not produce a mixed waste.

- A laboratory-scale non-radiological testing program was designed for the evaluation of the physical properties of the selected strippable coating products. Testing included tensile strength, resistance to abrasion, hardness testing, and ease of application and removal.

The objective for fiscal year 1998 (FY98) is to complete the non-radiological testing program and design and implement a radiological testing program. The search will also continue for existing commercially available strippable coating products that could be used at the DOE Complex. Finally, the results of both the radiological and non-radiological testing will be incorporated into the HCET multimedia information system for decontamination (MISD). 


\subsection{INTRODUCTION}

Strippable coatings are polymer mixtures, such as water-based organic polymers, that are applied to a surface by paint brush, roller, or spray applicator. As the polymer reacts, it attracts, absorbs, and chemically binds the contaminants; then, during the curing process, it mechanically locks the contaminants into the polymer matrix. The strength of these coatings may be enhanced by incorporating a fiber reinforcement (such as a cotton scrim) into the coating. Once the coating dries, it can be stripped manually from the surface. In the case of auto-release coatings, the mixture cracks, flakes, and is collected by vacuuming.

The surface properties of these coatings may be modified by applying a thin top coat (e.g., polyvinyl alcohol), which may provide a smoother, less permeable surface that would become less severely contaminated. In such a duplex, the thicker basis layer provides the required mechanical properties (e.g., strength and abrasion resistance) while the top layer provides protection from contamination. Once the strippable coating is removed, the loose surface contamination is removed with the coating, producing a dry, hard, non-airborne waste product.

The use of strippable coatings during D\&D operations has proved a viable option. These coatings can be used in the following three functions:

- As a protective coating when applied to an uncontaminated surface in an area where contamination is present so that on its removal the surface remains uncontaminated.

- As a decontamination agent when applied to a contaminated surface so that on its removal a significant decontamination of loose particulate activity is achieved.

- As a fixative or tie-down coating when applied to a contaminated surface so that any loose contamination is tied down, thus preventing the spread of contamination during subsequent handling.

A variety of strippable coatings are available commercially; however, not all of these products would be suitable for use in a nuclear facility. Many of the coating products were designed to protect a spray booth during painting operations. Of the dozens of strippable coatings available, only a handful were designed for use with radioactivity. These coatings can vary widely in their performance characteristics. Because of the lack of comprehensive and comparable data on these strippable coatings, (1) the D\&D professional may ignore strippable coatings with which they have no prior experience or (2) new coatings may be used without adequate performance data, which can increase the duration and cost of the D\&D tasks as well as increase the potential for personnel exposure to hazards.

\subsection{PURPOSE OF THIS INVESTIGATION}

The purpose of this investigation is to identify and laboratory-scale test strippable coatings that may be used in the D\&D of DOE environmental restoration sites. 
Assessments of selected strippable coating products will be conducted by HCET on the campus of FIU in Miami, Florida. Comprehensive and comparable data will be collected on the physical characteristics (e.g., tensile strength, abrasion resistance, and adhesion) of each coating as well as the ease of applying and removing (i.e., stripping) each product.

The data gathered as part of the testing of commercially available strippable coating products will be used to provide D\&D professionals with a single source of comparable information of data relating to physical characteristics, health and safety issues, waste generation, and performance. 


\subsection{PROJECT DESCRIPTION}

The overall project goals for this 2-year project are to (1) identify commercially available strippable coating products and vendors; (2) determine performance-based criteria for laboratoryscale testing of strippable coatings; and (3) perform the laboratory-scale testing of the selected products.

To facilitate the completion of these project goals, the following tasks were performed:

- Determine commercially available strippable coating products and vendors (FY97 and FY98).

- Perform a survey of DOE D\&D professionals to determine current uses of strippable coatings and suggested performance-based criteria for evaluation of strippable coating products (completed in FY97).

- Non-radiologically field test the strippable coatings that show the greatest promise of meeting the required performance parameters. Test coatings against the DOE survey performance-based criteria, ensuring the data is directly comparable (FY97 and FY98).

- Develop a radiological testing program for strippable coating products. Testing parameters will include determining decontamination factors and testing the coatings' ability to hold up in a radiation area (FY98).

- Field test the strippable coatings at a DOE facility. A minimum of six strippable coating products will be evaluated in FY98.

- Document the results of both radiological and non-radiological testing of strippable coatings (FY98).

- Enter performance data on strippable coatings into a multimedia information system (FY98). 


\subsection{RESULTS}

The following activities were completed in FY97:

- Identification of commercially available strippable coating products

- Survey of DOE D\&D professionals

- Design of non-radiological laboratory-scale testing of strippable coatings

\subsection{IDENTIFICATION OF COMMERCIALLY AVAILABLE STRIPPABLE COATING PRODUCTS}

Vendors of strippable coating products were identified using sources such as the Nuclear News Bulyer's Guide, the Thomas Register, the Internet, and literature obtained from the DOE Remedial Action Program Information Center (RAPIC) database. Each identified vendor was sent a survey form (Appendix $A$ ) requesting the purpose or uses of the strippable coating product and application and removal information. In addition to the survey form, literature and material safety data sheets (MSDSs) were obtained for each product.

Survey forms were sent to over 30 vendors, and responses were received from 15 stating that they did sell strippable coating products (Appendix B). Six vendors either no longer distribute or were not distributors of strippable coatings, and 14 vendors did not reply to the survey form. The vendors that distribute strippable coatings, their products, and the products' uses are presented in Table 1.

Table 1.

Strippable Coatings and Their Uses

\begin{tabular}{|l|l|c|c|c|}
\hline \multicolumn{1}{|c|}{ Vendor } & Strippable Coating Product & $\begin{array}{c}\text { Protective } \\
\text { Coating }\end{array}$ & Decontamination & Fixative \\
\hline A.P. Nonweiler & 33701 Blue/White Peelable & Yes & No & No \\
\hline Barry \& Sewall & Proxpeel & Yes & No & No \\
\hline Bartlett Services, Inc. & Stripcoat TLC & Yes & Yes & Yes \\
\hline Bartlett Services, Inc. & Stripcoat TLC Free & Yes & Yes & Yes \\
\hline Dip Seal Plastics, Inc. & Dip Seal & Yes & No & No \\
\hline Evans Manufacturing & Peel Coat System & Yes & No & No \\
\hline Fluid-Air Products, Inc. & G-116 & Yes & No & No \\
\hline FrHam Safety Products, Inc. & J.D.L. \#GP-RDM & No & Yes & No \\
\hline Master-Lee Decon Services & InstaCote ${ }^{8}$-ML & Yes & Yes & Yes \\
\hline Pentek, Inc. & Pentek 603/604 & No & Yes & No \\
\hline
\end{tabular}


Table 1.

Strippable Coatings and Their Uses (Continued)

\begin{tabular}{|c|c|c|c|c|}
\hline Vendor & Strippable Coating Product & $\begin{array}{c}\text { Protective } \\
\text { Coating }\end{array}$ & Decontamination & Fixative \\
\hline Spraylat Corp. & $\begin{array}{l}\text { Spraylat SC-1074A-1 and B-1 } \\
\text { SC-1090 top coating } \\
\text { Coverlac SC-247-2 }\end{array}$ & Yes & No & No \\
\hline $\begin{array}{l}\text { Technical Solutions \& } \\
\text { Systems, Inc. }\end{array}$ & $\begin{array}{l}\text { Tech Sol } 8001 \text { Reinforced } \\
\text { Peelable Coating }\end{array}$ & Yes & Yes & Yes \\
\hline $\begin{array}{l}\text { Technical Solutions \& } \\
\text { Systems, Inc. }\end{array}$ & $\begin{array}{l}\text { Tech Sol } 8002 \text { Peelable } \\
\text { Coating }\end{array}$ & Yes & Yes & Yes \\
\hline $\begin{array}{l}\text { Technical Solutions \& } \\
\text { Systems, Inc. }\end{array}$ & Tech Sol 8830 Fixative & Yes & No & Yes \\
\hline Thermo-Cote, Inc. & Protexo Cote V-12 White & Yes & No & No \\
\hline $\begin{array}{l}\text { Wampler Industrial } \\
\text { Coatings }\end{array}$ & 1331 Nanapeel & Yes & No & No \\
\hline Williams Power Corp. & $\begin{array}{l}\text { Carboline } 1146 \text { ALARA } \\
\text { Cavity Decon or Strippable }\end{array}$ & Yes & Yes & Yes \\
\hline
\end{tabular}

From the information collected from the vendor surveys, the following eight strippable coatings from five vendors were selected for the laboratory-scale testing:

- Carboline 1146 ALARA Strippable

- J.D.L. \# GP-RDM

- Pentek 603/604

- Stripcoat TLC
- Stripcoat TLC Free

- TechSol 8001 Reinforced Peelable Coating

- Tech Sol 8002 Peelable Coating

- TechSol 8830 Fixative

These coatings were determined to be the most likely to meet the DOE Complex needs and the performance-based criteria established from the DOE D\&D professionals survey (see Section $3.2)$.

MasterDecon coating was not chosen for testing in FY97 because of the concern of working with isocyanates. HCET will attempt to test this coating during FY98.

\subsection{SURVEY OF DOE D\&D PROFESSIONALS}

A survey form was generated by HCET for DOE D\&D professionals (Appendix C) to complete requesting information about the current use of strippable coatings, future possible uses of these coatings, and the performance criteria these coatings should meet. The survey was distributed by 
the Deactivation and Decommissioning Focus Area Manager at FETC to both DOE and site technology coordination group (STCG) personnel at over a dozen DOE facilities.

Responses were received from the following locations:

- Fluor Daniel Fernald

- Idaho/Lockheed Martin Idaho Technologies Company

- Los Alamos National Laboratory (LANL)

- Y-12, MK-Ferguson of Oak Ridge

A complete listing of the information gathered from these surveys can be found in Appendix D; however, the summary below highlights some of the more important information.

The following strippable coating products are currently being used at DOE facilities (or have been used in the past):

- Bartlett Stripcoat TLC and TLC Free

- Carboline 1146 ALARA Cavity Decon (previously Imperial)

- Sensor Coat (developed at LANL, not commercially available)

- PeelAway

The substrate materials that the strippable coatings were applied to include:

- metals-stainless steel, carbon steel, and painted metals

- concrete

- concrete masonry units (CMU)-block or brick

- galvanized steel
- DOE Nevada Operations

- Rocky Flats Environmental Technology Site/RFFO

- Westinghouse Savannah River Company

Examples of the performance criteria considered important by these facilities in using a strippable coating product include:

- The decontamination factor for removal of loose contamination. Must reduce airborne activity.

- Fast cure time before either second coat can be applied or the coating can be removed.

- Must be easy to apply and remove.

- Must be able to be applied at temperatures ranging from $20^{\circ}$ to $80^{\circ} \mathrm{F}$. Should be able to cure at $45^{\circ} \mathrm{F}$.

- Must be strong and pliable—strong enough to be removed in reasonably sized sheets. 
- Cannot be made with organic solvents.

- Must not create a mixed waste for disposal. Must be applied and removed with minimal waste generation.

- Should be able to leave product on surface for at least 30 days.

- Should remain stable during its use to contain the contamination.

Parts of the performance criteria listed above can be determined from the vendor survey information (e.g., temperature range for application) or the product's MSDS (e.g., organic solvents and mixed waste). The remaining criteria were used in the development of the HCET laboratory-scale testing program described in Section 3.3 below.

\subsection{DESIGN OF NON-RADIOLOGICAL LABORATORY-SCALE TESTING OF STRIPPABLE COATINGS}

To establish a testing program that would provide fair, comparable results for each of the strippable coating products, American Society for Testing and Materials (ASTM) standards for the testing of paints and coatings were reviewed. Testing standards relating to material application, strength, adhesion, and hardness were chosen for the HCET laboratory-scale testing program.

Table 2 provides a comparison of the performance-based criteria identified by the DOE D\&D professionals survey (see Section 3.2) and the ASTM standards chosen for the HCET testing. Where ASTM standards did not exist, (e.g., testing the removal of coatings), procedures were developed by HCET:

Nine internal HCET procedures were written for the laboratory-scale testing of strippable coatings. The procedure names and a brief description of each are as follows:

\subsubsection{Use of the Super Nova SP Spray Applicator}

This procedure describes the proper operation, safety, cleanup, and storage of the Super Nova SP airless paint sprayer. This unit will be used for the application of strippable coatings on test panels. 
Table 2.

Comparison of Performance-based Criteria with Testing Methods

\begin{tabular}{|c|c|c|}
\hline Performance-based Criteria & ASTM \# & ASTM Method Name \\
\hline Must be easy to apply and remove. & D $823-95$ & $\begin{array}{l}\text { Producing Films of Uniform Thickness of Paint, Varnish, } \\
\text { and Related Products on Test Panels } \\
\text { (Practice D) }\end{array}$ \\
\hline (a) & D $4414-84$ & $\begin{array}{l}\text { Measurement of Wet Film Thickness by Notch Gages } \\
\text { (Procedure A) }\end{array}$ \\
\hline (a) & D $1400-87$ & $\begin{array}{l}\text { Nondestructive Measurement of Dry Film Thickness of } \\
\text { Nonconductive Coatings Applied to a Nonferrous Metal } \\
\text { Base }\end{array}$ \\
\hline (a) & D $1005-84$ & $\begin{array}{l}\text { Measurement of Dry-Film Thickness of Organic Coatings } \\
\text { Using Micrometers }\end{array}$ \\
\hline $\begin{array}{l}\text { Fast cure time before second coat } \\
\text { can be applied or the coating can } \\
\text { be removed. }\end{array}$ & D $1640-95$ & $\begin{array}{l}\text { Drying, Curing, or Film Formation of Organic Coatings at } \\
\text { Room Temperature }\end{array}$ \\
\hline Product must be strong and pliable. & D $3363-92 a$ & Film Hardness by Pencil Test \\
\hline Product must be strong and pliable. & D $2370-92$ & Tensile Properties of Organic Coatings \\
\hline Product must be strong and pliable. & D $4060-95$ & $\begin{array}{l}\text { Abrasion Resistance of Organic Coatings by the Taber } \\
\text { Abraser }\end{array}$ \\
\hline $\begin{array}{l}\text { Should be able to leave in place for } \\
\text { at least } 30 \text { days. }\end{array}$ & D $3359-93$ & $\begin{array}{l}\text { Measuring Adhesion by Tape Test } \\
\text { (Method A) }\end{array}$ \\
\hline $\begin{array}{l}\text { Should be able to leave in place for } \\
\text { at least } 30 \text { days. }\end{array}$ & D $4141-82$ & $\begin{array}{l}\text { Conducting Accelerated Outdoor Exposure Tests of } \\
\text { Coatings } \\
\text { (Procedure A) }\end{array}$ \\
\hline (b) & D $660-93$ & Evaluating Degree of Checking of Exterior Paints \\
\hline (b) & D $661-93$ & Evaluating Degree of Cracking of Exterior Paints \\
\hline (b) & D 714-87 & Evaluating Degree of Blistering of Paints \\
\hline Decontamination factors. & $\begin{array}{l}\text { (INEL } \\
\text { method) }\end{array}$ & Simulated Determination of Decontamination Factors \\
\hline
\end{tabular}

(a) These methods combined with D 823-95 constitute the application procedure.

(b) These methods combined with D 4141-82 constitute the exposure testing procedure. 


\subsubsection{Testing the Application of Organic Coatings}

This procedure describes the evaluation of the application, drying, and curing process for strippable coatings. Testing collects information such as:

- Application method (e.g., spraying, rolling, paint brush) of strippable coating to a $1 \mathrm{ft} \times 1 \mathrm{ft}$ stainless steel test panel (Figure 1)

- Ease of application (e.g., recording problems such as clogging of spray applicator nozzle and whether the coating runs or drips off of test panels at application)

- Ease of obtaining proper thickness of coating

- Timing for various stages of dryness or curing for each coating (e.g., set-to-touch time vs. dry-hard time)

- Visual appearance of coating once applied

- Ease of removal of strippable coating from stainless steel test panel

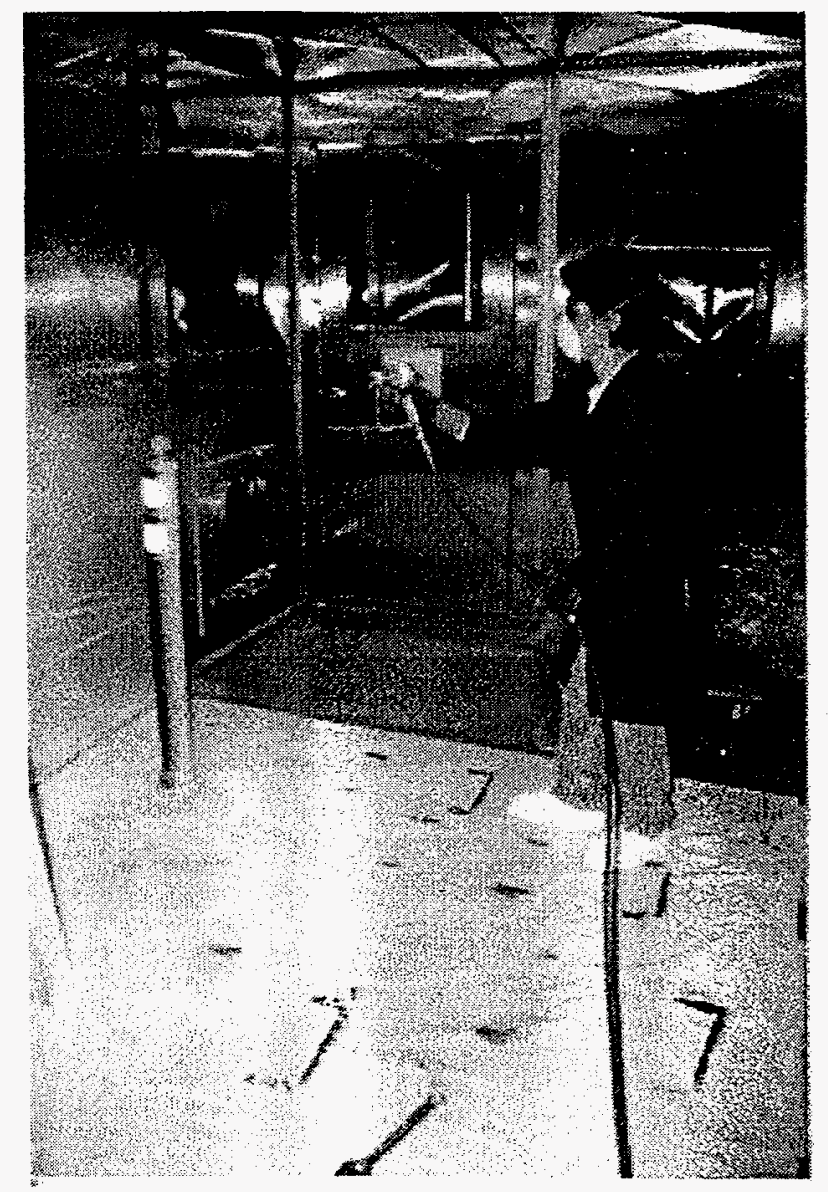

Figure 1. Spray application of strippable coatings. 


\subsubsection{Application and Removal of Strippable Coatings on Difficult Materials}

This procedure describes the evaluation of the application and removal of strippable coatings on a variety of materials and shapes including the following:

- wood

- concrete floor (painted and unpainted - see Figure 2)

- galvanized piping

- brick wall (painted)

- carbon steel (painted plates and I-beam)

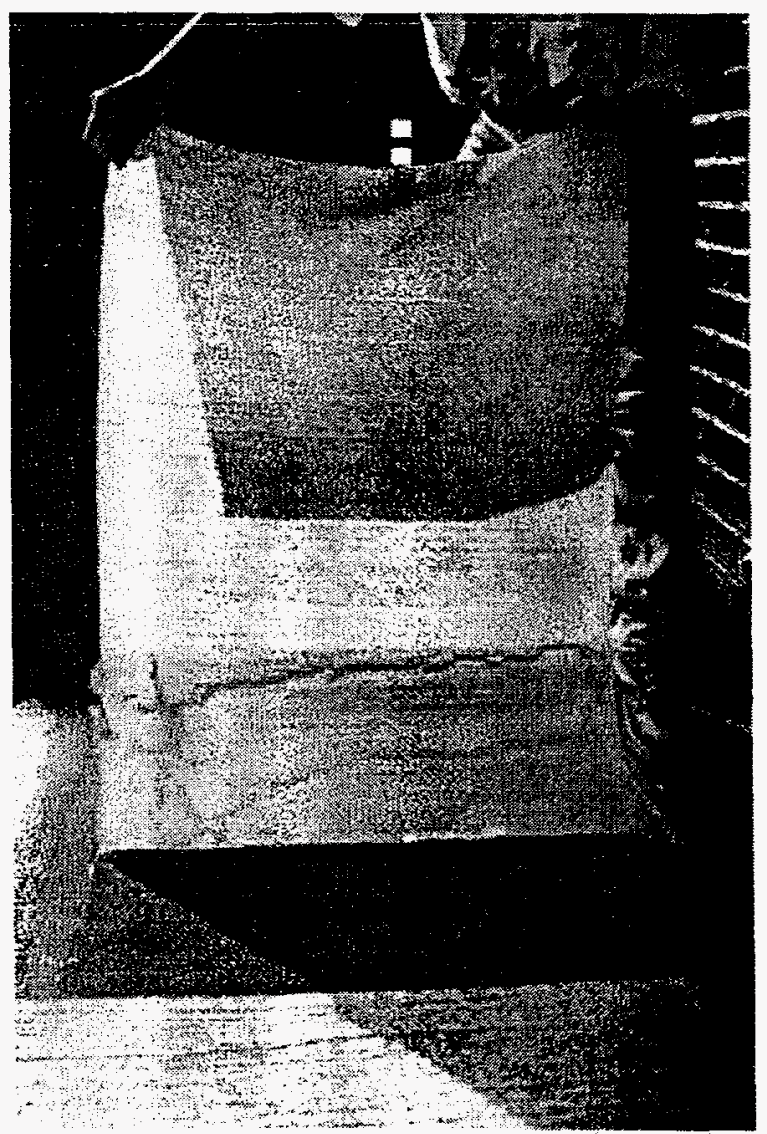

Figure 2. Removal of strippable coating from painted and unpainted concrete.

\subsubsection{Conducting Accelerated Outdoor Exposure Testing of Organic Coatings}

This procedure describes the evaluation of the exterior durability of coatings applied to metal substrates over a period of time (e.g., one month). The coatings are applied to metal panels, 
which are then held in place on a black metal box and left outside exposed to the elements and facing the equator at a 5-degree angle (Figure 3). The black box is a good conductor of heat, producing greater panel temperatures during irradiation by the sun and longer time of wetness during rain. This testing was performed to evaluate the durability of strippable coatings that may be used as protective barriers on materials that may be used outdoors.

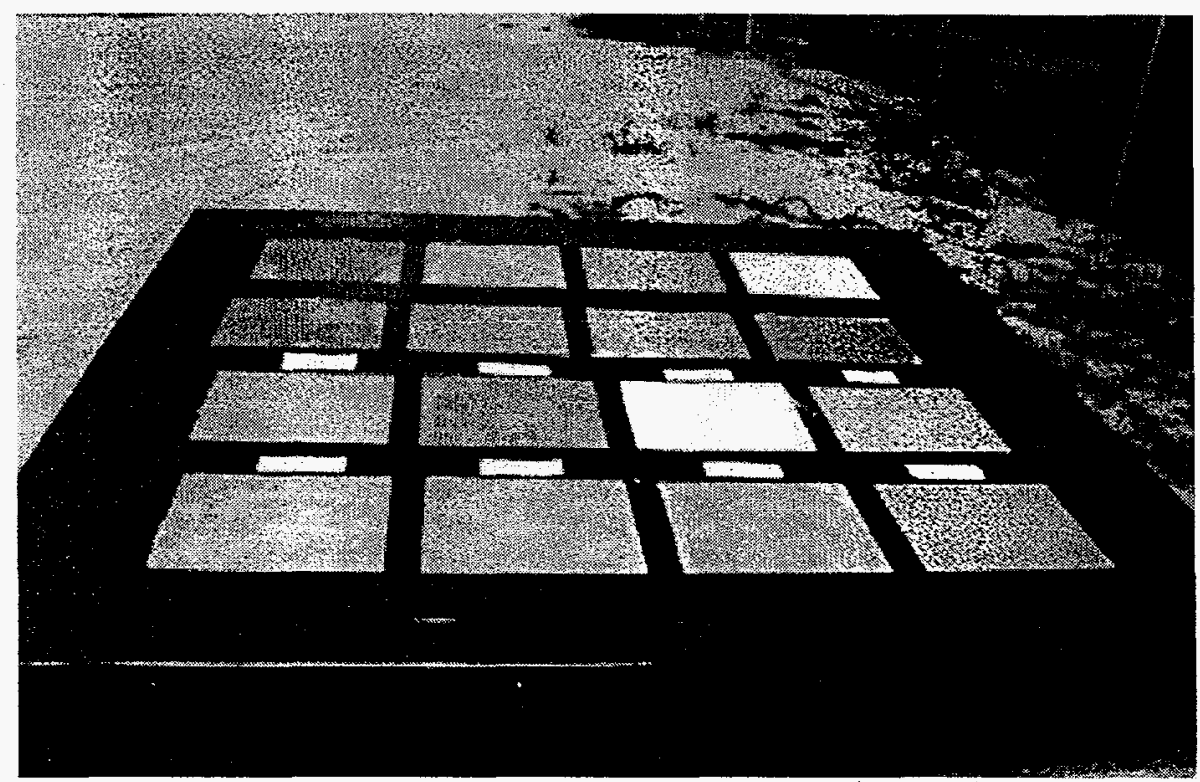

Figure 3. Exposure testing.

\subsubsection{Measuring Abrasion Resistance of Organic Coatings}

This procedure describes the evaluation of the resistance of surfaces to rubbing abrasion. The instrument used for this testing is a Taber Abraser (Figure 4). The characteristic rub-wear action is produced by the contact of a test sample turning on a vertical axis against the sliding rotation of two abrading wheels. One abrading wheel rubs the specimen outward toward the periphery and the other, inward, toward the center. The resulting abrasion marks form a pattern of crossed arcs over an area of approximately $30 \mathrm{~cm}^{2}$. This testing was performed to evaluate the durability of a strippable coating that would be used as a protective barrier or fixative and is expected to remain in place and withstand normal handling. 


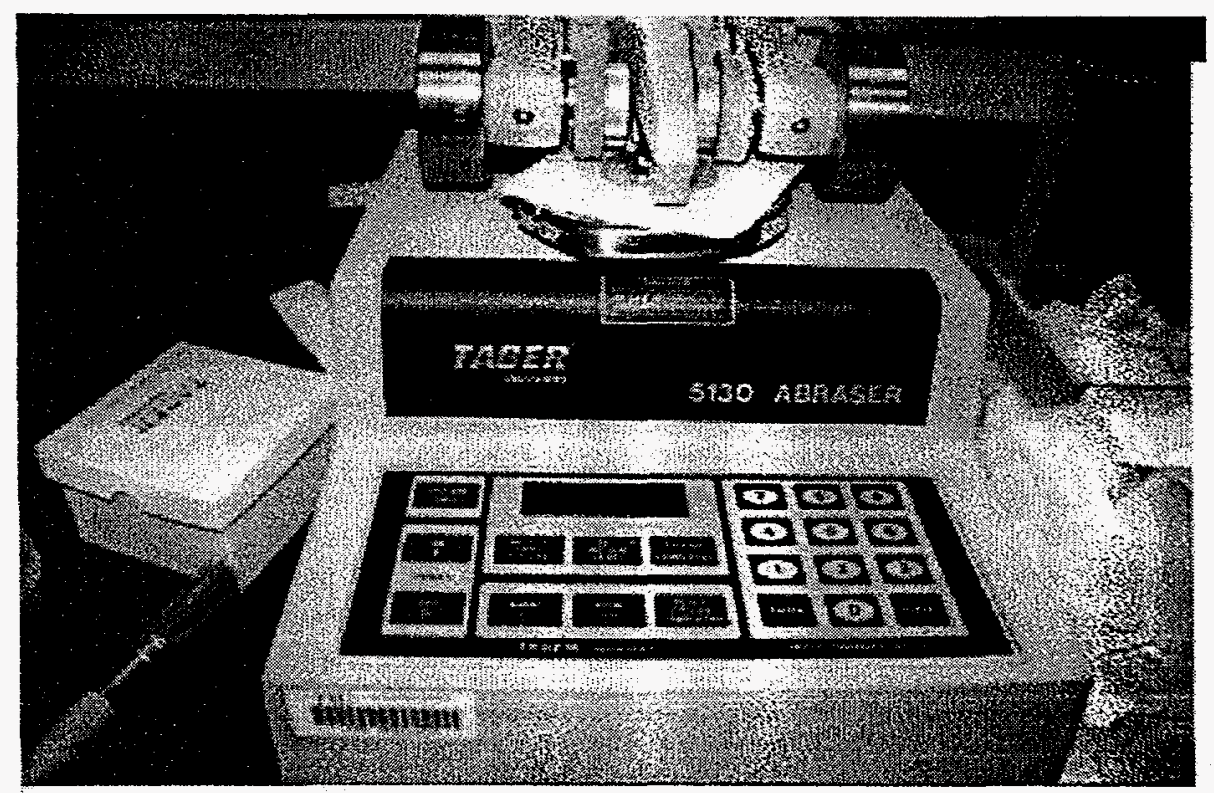

Figure 4. Taber Abraser.

\subsubsection{Measuring Adhesion of Organic Coatings}

This procedure describes the evaluation of the adhesion properties of the strippable coatings to metallic substrates by applying and removing pressure-sensitive tape over cuts made in the film (Figure 5). This testing was performed to evaluate the ability of the strippable coating to remain fixed to the substrate until the time to remove the coating but to come off when the operator chooses.

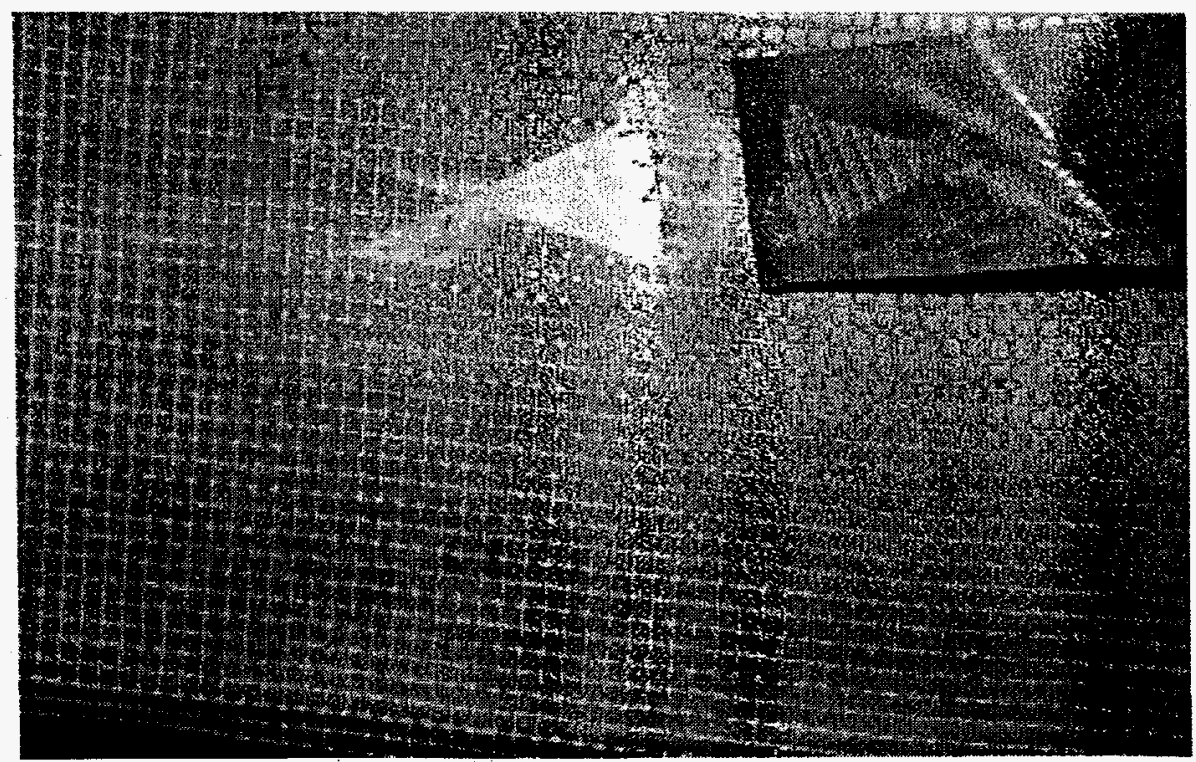

Figure 5. Adhesion testing. 


\subsubsection{Measuring Film Hardness of Organic Coatings}

This procedure describes the evaluation of the resistance of the strippable coatings to surface scratching. This test uses pencil leads of various hardness, which are drawn along the coated panel starting with the hardest pencil and continuing down the hardness scale (Figure 6). This procedure is continued until (1) the pencil does not cut into or gouge the film (pencil hardness) or (2) the pencil does not scratch the film (scratch hardness). This testing was performed to evaluate the durability of a strippable coating that would be used as a protective barrier or fixative and is expected to remain in place and withstand normal handling.

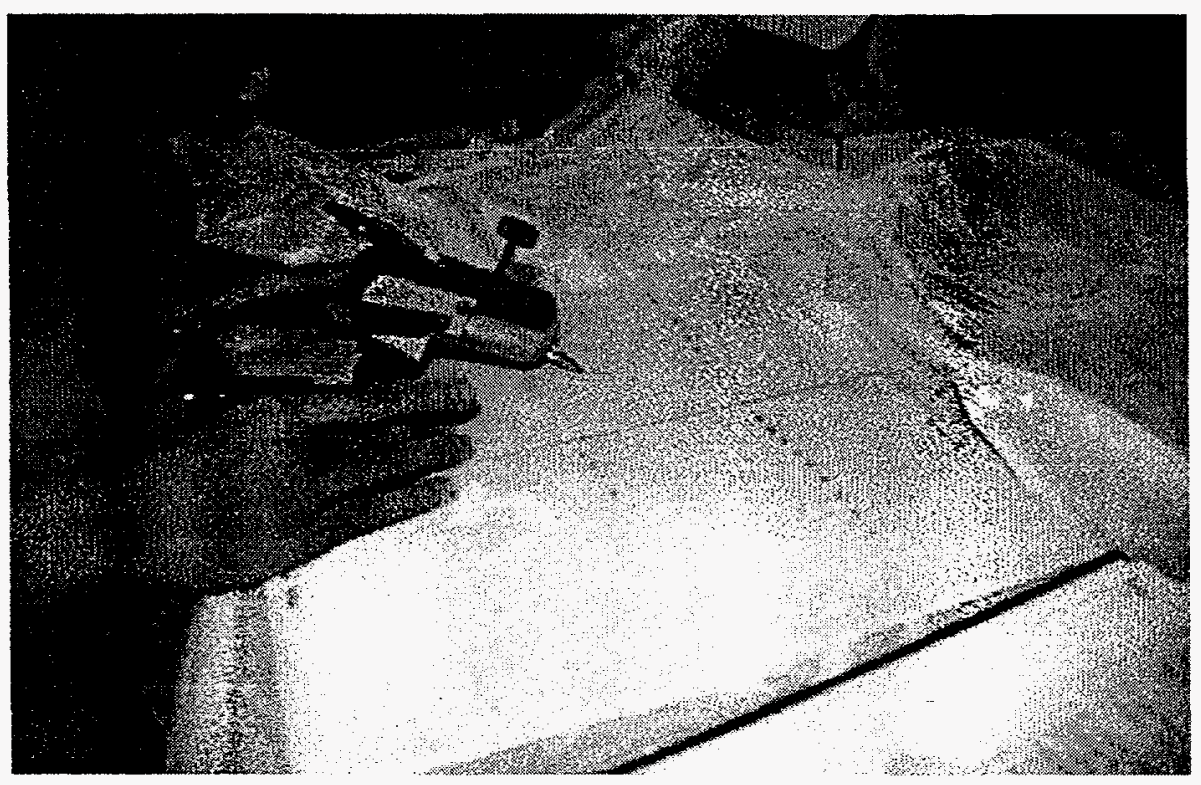

Figure 6. Pencil hardness testing.

\subsubsection{Measuring Tensile Strength of Organic Coatings}

To evaluate the elongation, tensile strength, and stiffness of strippable coatings when tested as free films. This testing is performed to evaluate the strength of the strippable coating especially if the coating is expected to be removed (e.g., stripped) from the substrate in a single piece.

\subsubsection{Determination of Decontamination Factors for Strippable Coatings}

This procedure is based on the paper Development of Simulated Contamination (SIMCON) and Miscellaneous Decontamination Scoping Tests, WINCO-1188, written by R. L. Demmer in January 1994 at Westinghouse Idaho Nuclear Company, Inc. to measure the ability of strippable coating products to remove loose contamination from substrates using simulated contaminants (e.g., using cesium and zirconium salts). Analytical determination of the "before and after" results were measured using a Spectrace 9000 portable $x$-ray fluorescence (XRF) unit. This test 
was performed as a side-by-side comparison of the decontamination ability of the strippable coating products.

Additional testing expected to be performed by the HCET analytical laboratory includes the evaluation of each strippable coating by scanning electron microscopy (SEM) and thermal analysis. 


\subsection{ACTIVITIES PLANNED FOR FY98}

\subsection{COMPLETION OF NON-RADIOLOGICAL TESTING}

The non-radiological testing plan that was designed in FY97 will be used to evaluate strippable coatings from five vendors. See Section 3.0 for a description of this testing.

\subsection{DESIGN OF RADIOLOGICAL TESTING PLAN}

This task involves the review of ASTM methods for testing materials such as strippable coatings in radiation environments (e.g., method E 1420 Standard Practice for Specifying Polymeric Materials for Service in Ionizing Radiation Environments) as well as literature describing prior radiological testing of strippable coating products to establish the radiological testing program for HCET. This program will be documented in the form of a test plan.

\subsection{IDENTIFICATION OF RADIOLOGICAL FACILITY(IES) TO PERFORM TESTING}

Once the radiological testing procedures have been identified in 4.2 , the facility or facilities that will perform each of these procedures will be identified and procured. It is expected that part of the testing for determining decontamination factors will be performed at HCET and part at a DOE facility or other radiological testing facility. The ionizing radiation exposure testing will be performed at either a DOE facility or another radiological facility.

\subsection{RADIOLOGICAL TESTING OF TARGETED STRIPPABLE COATING PRODUCTS}

Using the radiological test plan prepared in 4.2, a minimum of six (6) strippable coating products will be tested during FY98. Testing is expected to include the determination of decontamination factors for each strippable coating product and the effect of exposure to ionizing radiation on the physical and chemical properties of the coatings.

\subsection{NON-RADIOLOGICAL TESTING OF NEWLY IDENTIFIED STRIPPABLE COATING PRODUCTS}

Any new strippable coating product identified in FY98 that shows the promise of meeting the required performance parameters will be tested using the non-radiological testing plan developed in FY97. If possible, this newly identified product will also be included in the radiological test plan as identified in 4.2 . 


\subsection{GENERATION AND POPULATION OF MULTIMEDIA INFORMATION SYSTEM FOR STRIPPABLE COATING DATA}

The HCET multimedia information system will be updated to reflect the additional data fields that result from the testing of strippable coating products. Modifications to the multimedia information system database scheme will be performed by the D\&D software analyst or his or her designee, and subsequent population of the testing information will be performed by data entry personnel at HCET. 


\subsection{CONCLUSIONS}

The preliminary activities needed to begin the evaluation of strippable coatings are complete. These activities include the following:

- Identification of commercially available strippable coating products and vendors

- Determination of performance-based criteria that are of concern to DOE D\&D professionals

- Design of the laboratory-scale testing for strippable coating products that is based on the above performance-based criteria

Procedures were written and equipment was purchased for the laboratory-scale testing program. Testing began in November 1997 and is expected to be completed in early January 1998.

Second-year activities include the completion of the non-radiological testing and the design and implementation of a radiological testing program. Radiological testing is expected to include the determination of decontamination factors using radiological material (e.g., uranium, cesium) and radiological exposure testing. The results of both testing programs will be incorporated in the HCET multimedia information system for D\&D professionals to access. 


\subsection{REFERENCES}

Adams, J.W., Dougherty, D.R., and Barletta, R.E., 1984, "A Strippable Coating Used for the TMI-2 Reactor Building Decontamination.” Proceedings, Waste Management '84. Tucson, AZ, Vol. 2, pp. 483-487.

Demmer, R.L., 1994, Development of Simulated Contamination (SIMCON) and Miscellaneous Decontamination Scoping Tests. WINCO-1188, Westinghouse Idaho Nuclear Company, Inc. for the U.S. Department of Energy, Idaho Operations Office, Idaho Falls, ID.

Oak Ridge National Laboratory (ORNL), 1993, Oak Ridge National Laboratory Technology Logic Diagram, ORNL/M-2752, U.S. Department of Energy, Oak Ridge, Tennessee.

Turner, A.D. and Dalton, J.T., 1984, "A Review of the Application of Temporary and Permanent Coatings for the Reduction of Activity Hold-up and Increased Ease of Decontamination." EUR9095EN (DoE/RW/84.016), Commission of the European Communities, Directorate-General Information Market and Innovation, Luxembourg.

Turner, A.D., Worrall, G, and Dalton, J.T., 1987, "A Survey of Strippable and Tie-Down Coatings for Use in the Decommissioning of Alpha-active Facilities", AERE R 12474 (DoE/RW/87.030), United Kingdom Atomic Energy Authority, Harwell Laboratory, Oxfordshire

U.S. Department of Energy, 1994, Decommissioning Handbook, DOE/EM-0142P. 
APPENDIX A

\section{VENDOR SURVEY FORM}

Vendor Information:

\begin{tabular}{|l|l|}
\hline Contact Name: \\
\hline Company Name: \\
\hline Address: \\
\hline Phone: & Fax: \\
\hline
\end{tabular}

1. Name of strippable coating product:

2. Cost of coating: /per

3. Strippable coating is effective on what media: (circle all that apply)
a. - metal: smooth and/or rough
b. concrete: wall and/or floor
c. transite
d. equipment
e. other:

4. Coating is applied using: (circle all that apply)
a. spray
b. brush
c. roller
d. other:

5. Coating is removed by:
a. removing in whole strip
b. becoming brittle, breaking off in small pieces, vacuuming
c. other:

6. Coating is typically used to: (circle all that apply)
a. remove paint
b. decontaminate
c. act as a barrier against contamination (e.g. rad, metals)
d. fix contamination to surface
e. other:

7. If coating removes contaminants, which contaminants: (circle all that apply)
a. radionuclides: all or individual if individual, list: 
b. metals: __ all or ___ individual

if individual, list:

c. organics: __all or __ individual

if individual, list:

8. Protective equipment required when applying strippable coating: (circle all that apply)

a. safety glasses

b. safety shoes

c. gloves

d. respirator

e. personnel protective clothing

f. other:

9. Coating can be applied to surfaces when the external temperature is in what range:

10. Rate ability of strippable coating to resist scuffs and abrasions:

$\begin{array}{ccccc}\text { none } & & & & \text { strong } \\ 1 & 2 & 3 & 4 & 5\end{array}$

11. Additional information:

Please include a copy of a Material Safety Data Sheet (MSDS) and literature describing strippable coating product. 
Table B.1. Strippable Coating Vendor Information

\begin{tabular}{|c|c|c|c|c|c|}
\hline $\begin{array}{l}\text { Strippable } \\
\text { Coating } \\
\text { Product } \\
\text { Name }\end{array}$ & Vendor Name & Vendor Address & $\begin{array}{l}\text { Vendor Phone } \\
\text { Number }\end{array}$ & $\begin{array}{l}\text { Vendor Fax } \\
\text { Number }\end{array}$ & Contact Person \\
\hline $\begin{array}{l}33701 \\
\text { Blue/White } \\
\text { Peelable }\end{array}$ & $\begin{array}{l}\text { A.P. } \\
\text { Nonweiler }\end{array}$ & $\begin{array}{l}3321 \text { North Shore Dr. } \\
\text { Oshkosh, WI } 54901\end{array}$ & (414) $231-0850$ & (414) $231-8085$ & $\begin{array}{l}\text { Dennis } \\
\text { Lewandowski }\end{array}$ \\
\hline Proxpeel & $\begin{array}{l}\text { Barry \& } \\
\text { Sewell }\end{array}$ & $\begin{array}{l}2001 \text { Broadway N.E. } \\
\text { Minneapolis, MN } \\
55413\end{array}$ & (612) $331-6170$ & (612) 378-6340 & Dan Krawczyk \\
\hline $\begin{array}{l}\text { Stripcoat } \\
\text { TLC } \\
\text { Stripcoat } \\
\text { TLC free }\end{array}$ & $\begin{array}{l}\text { Bartlett } \\
\text { Services, Inc. }\end{array}$ & $\begin{array}{l}60 \text { Industrial Park } \\
\text { Road } \\
\text { Plymouth, MA } 02560\end{array}$ & $\begin{array}{l}\text { (508) } 746-6464 \\
\text { ext. } 305\end{array}$ & (508) $830-3616$ & Paul Lovendale \\
\hline Dip Seal & $\begin{array}{l}\text { Dip Seal } \\
\text { Plastics, Inc. }\end{array}$ & $\begin{array}{l}23123 \text { Ave. } \\
\text { Rockford, IL } 61104\end{array}$ & (815) 398-3533 & (815) 398-0353 & Stan Jones \\
\hline $\begin{array}{l}\text { Peel Coat } \\
\text { System } \\
\text { (200 Top } \\
\text { Coat } / 912 \\
\text { Base) }\end{array}$ & $\begin{array}{l}\text { Evans } \\
\text { Manufacturing }\end{array}$ & $\begin{array}{l}1330 \text { Souter } \\
\text { Troy MI } 48083\end{array}$ & (810) 583-9890 & (810) 583-2050 & Tom Evans \\
\hline G-116 & $\begin{array}{l}\text { Fluid-Air } \\
\text { Products, Inc. }\end{array}$ & $\begin{array}{l}719 \text { Rudder Rd. } \\
\text { Fenton, MO } 63026\end{array}$ & (314) $349-4900$ & (314) 349-4942 & ---- \\
\hline $\begin{array}{l}\text { J.D.L. \# } \\
\text { GP-RDM }\end{array}$ & $\begin{array}{l}\text { FrHam Safety } \\
\text { Products, Inc. }\end{array}$ & $\begin{array}{l}295 \text { Parker St. } \\
\text { P.O. Box 51957 } \\
\text { Springfield, MA } \\
01151\end{array}$ & (413) 543-6911 & (413) 543-6989 & $\begin{array}{l}\text { Fred } \mathrm{H} \text {. } \\
\text { Nance, Jr. }\end{array}$ \\
\hline $\begin{array}{l}\text { InstaCote }_{-} \\
\text {ML }\end{array}$ & $\begin{array}{l}\text { Master-Lee } \\
\text { Decon } \\
\text { Services }\end{array}$ & $\begin{array}{l}350 \text { Miller Rd. } \\
\text { Medford, NJ } 08055\end{array}$ & (609) 654-6161 & (609) 654-1404 & Bob Burns \\
\hline $\begin{array}{l}\text { Pentek } \\
603 / 604\end{array}$ & Pentek, Inc. & $\begin{array}{l}1026 \text { Fourth Ave. } \\
\text { Coraopolis, PA } 15108\end{array}$ & (412) 262-0725 & (412) 262-0731 & Nancy Moore \\
\hline $\begin{array}{l}\text { Spraylat } \\
\text { Preservation } \\
\text { System }\end{array}$ & $\begin{array}{l}\text { Spraylat } \\
\text { Corporation }\end{array}$ & $\begin{array}{l}716 \text { South Columbus } \\
\text { Avenue } \\
\text { Mount Vernon, NY } \\
10550\end{array}$ & (914) 699-3030 & (914) 699-3035 & $\begin{array}{l}\text { Jeanette T. } \\
\text { Leissler }\end{array}$ \\
\hline
\end{tabular}


Table B.1. Strippable Coating Vendor Information (Continued)

\begin{tabular}{|c|c|c|c|c|c|}
\hline $\begin{array}{l}\text { Strippable Coating } \\
\text { Product Name }\end{array}$ & $\begin{array}{l}\text { Vendor } \\
\text { Name }\end{array}$ & Vendor Address & $\begin{array}{c}\text { Vendor Phone } \\
\text { Number }\end{array}$ & $\begin{array}{l}\text { Vendor Fax } \\
\text { Number }\end{array}$ & $\begin{array}{l}\text { Contact } \\
\text { Person }\end{array}$ \\
\hline 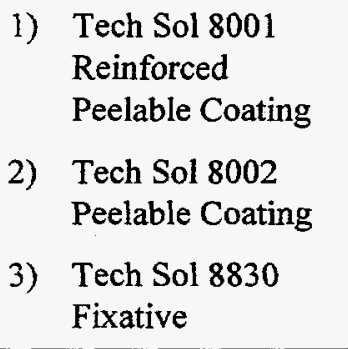 & $\begin{array}{l}\text { Technical } \\
\text { Solutions \& } \\
\text { Systems, } \\
\text { Inc. }\end{array}$ & $\begin{array}{l}\text { P.O. Box } 357 \\
\text { Elizabethton, TN } \\
37644\end{array}$ & $1-888-275-4877$ & (423) 926-0768 & $\begin{array}{l}\text { Bill } \\
\text { Reynolds }\end{array}$ \\
\hline $\begin{array}{l}\text { Protexo Cote V-12 } \\
\text { White }\end{array}$ & $\begin{array}{l}\text { Thermo- } \\
\text { Cote, Inc. }\end{array}$ & $\begin{array}{l}295 \text { Vreeland Ave. } \\
\text { Paterson, NJ } 07543\end{array}$ & (201) 345-6206 & (201) 278-7512 & $\begin{array}{l}\text { Larry } \\
\text { Kersen }\end{array}$ \\
\hline 1331 Nanapeel & $\begin{array}{l}\text { Wampler } \\
\text { Industrial } \\
\text { Coatings }\end{array}$ & $\begin{array}{l}3333 \text { Willow } \\
\text { Spring Rd. } \\
\text { Harrisonburg, VA } \\
22801\end{array}$ & (540) 434-4201 & (540) 434-1958 & $\begin{array}{l}\text { Todd or } \\
\text { Tariq }\end{array}$ \\
\hline $\begin{array}{l}\text { Carboline } 1146 \\
\text { ALARA Cavity Decon } \\
\text { or Strippable }\end{array}$ & $\begin{array}{l}\text { Williams } \\
\text { Power } \\
\text { Corp. }\end{array}$ & $\begin{array}{l}2076 \text { West Park } \\
\text { Place } \\
\text { Stone Mountain, } \\
\text { GA } 30087\end{array}$ & (770) 879-2455 & (717) $275-3285$ & $\begin{array}{l}\text { T.J. } \\
\text { McNamara }\end{array}$ \\
\hline
\end{tabular}




\section{STRIPPABLE COATING PRODUCT INFORMATION}

Table B.2. Application and Removal

\begin{tabular}{|c|c|c|c|c|c|}
\hline $\begin{array}{c}\text { Strippable } \\
\text { Coating } \\
\text { Product } \\
\text { Name }\end{array}$ & $\begin{array}{l}\text { Applicable } \\
\text { Media }\end{array}$ & $\begin{array}{l}\text { Application } \\
\text { Method }\end{array}$ & $\begin{array}{l}\text { Removal } \\
\text { Method }\end{array}$ & $\begin{array}{l}\text { Purpose of } \\
\text { Coating }\end{array}$ & $\begin{array}{l}\text { Loose Surface } \\
\text { Contaminants } \\
\text { Removed }\end{array}$ \\
\hline $\begin{array}{l}33701 \\
\text { Blue/White } \\
\text { Peelable }\end{array}$ & $\begin{array}{l}\text { Metal } \\
\text { Concrete } \\
\text { Transite } \\
\text { Equipment }\end{array}$ & $\begin{array}{l}\text { Spray } \\
\text { Brush } \\
\text { Roller }\end{array}$ & $\begin{array}{l}\text { Removed in } \\
\text { whole strips }\end{array}$ & $\begin{array}{l}\text { Protective barrier } \\
\text { for shipping } \\
\text { material }\end{array}$ & ---- \\
\hline Proxpeel & $\begin{array}{l}\text { Metal } \\
\text { Concrete } \\
\text { Equipment } \\
\text { Spray Booth }\end{array}$ & $\begin{array}{l}\text { Spray } \\
\text { Brush }\end{array}$ & $\begin{array}{l}\text { Removed in } \\
\text { whole strips }\end{array}$ & $\begin{array}{l}\text { Spray booth } \\
\text { coating }\end{array}$ & ---- \\
\hline $\begin{array}{l}\text { Stripcoat TLC } \\
\text { Stripcoat TLC } \\
\text { free }\end{array}$ & $\begin{array}{l}\text { Metal } \\
\text { Concrete } \\
\text { Transite } \\
\text { Equipment } \\
\text { Any non- } \\
\text { oily surface }\end{array}$ & $\begin{array}{l}\text { Spray } \\
\text { Brush } \\
\text { Roller }\end{array}$ & $\begin{array}{l}\text { Removed in } \\
\text { whole strips } \\
\text { or can be } \\
\text { scored with } \\
\text { knife for } \\
\text { smaller strips }\end{array}$ & $\begin{array}{l}\text { Decontamination } \\
\text { Fixative } \\
\text { Protective Barrier }\end{array}$ & $\begin{array}{l}\text { All radionuclides } \\
\text { All metals } \\
\text { All organics }\end{array}$ \\
\hline Dip Seal & $\begin{array}{l}\text { Surfaces that } \\
\text { can } \\
\text { withstand } \\
350^{\circ} \mathrm{F}\end{array}$ & $\begin{array}{l}\text { Brush } \\
\text { Dipping }\end{array}$ & $\begin{array}{l}\text { Removed in } \\
\text { whole strips }\end{array}$ & $\begin{array}{l}\text { Protects against } \\
\text { corrosion, nicking, } \\
\text { scratching }\end{array}$ & ----- \\
\hline $\begin{array}{l}\text { Peel Coat } \\
\text { System } \\
(200 \text { Top } \\
\text { Coat } / 912 \\
\text { Base) }\end{array}$ & Metal & Hot dip & $\begin{array}{l}\text { Removed in } \\
\text { whole strips }\end{array}$ & $\begin{array}{l}\text { Protects cutting } \\
\text { tools from rust and } \\
\text { abrasion }\end{array}$ & ---- \\
\hline G-116 & $\begin{array}{l}\text { Smooth } \\
\text { metal }\end{array}$ & Spray & $\begin{array}{l}\text { Removed in } \\
\text { whole strips }\end{array}$ & Protective barrier & ---- \\
\hline $\begin{array}{l}\text { J.D.L. \# } \\
\text { GP-RDM }\end{array}$ & $\begin{array}{l}\text { Metal } \\
\text { Concrete }\end{array}$ & $\begin{array}{l}\text { Spray } \\
\text { Brush } \\
\text { Roller }\end{array}$ & $\begin{array}{l}\text { Removed in } \\
\text { whole strips }\end{array}$ & Decontaminate & All radionuclides \\
\hline InstaCote ${ }^{\circledR}-\mathrm{ML}$ & $\begin{array}{l}\text { Metal } \\
\text { Concrete } \\
\text { Transite } \\
\text { Equipment } \\
\text { Wood } \\
\text { Gloveboxes }\end{array}$ & Spray & $\begin{array}{l}\text { Removed in } \\
\text { whole strips } \\
\text { Cut into small } \\
\text { strips }\end{array}$ & $\begin{array}{l}\text { Decontaminate } \\
\text { Fixative } \\
\text { Protective barrier } \\
\text { Remove loose paint } \\
\text { Leak protection }\end{array}$ & $\begin{array}{l}\text { All radionuclides } \\
\text { All metals } \\
\text { All organics }\end{array}$ \\
\hline $\begin{array}{l}\text { Pentek } \\
603 / 604\end{array}$ & $\begin{array}{l}\text { Metal } \\
\text { ( } 603 \text { for } \\
\text { carbon steel } \\
\text { only) } \\
\text { Concrete }\end{array}$ & $\begin{array}{l}\text { Brush } \\
\text { Roller }\end{array}$ & $\begin{array}{l}\text { Brittle, breaks } \\
\text { off in small } \\
\text { pieces }\end{array}$ & Decontaminate & $\begin{array}{l}\text { All radionuclides } \\
\text { All metals }\end{array}$ \\
\hline
\end{tabular}


Table B.2. Application and Removal (Continued)

\begin{tabular}{|c|c|c|c|c|c|}
\hline $\begin{array}{l}\text { Strippable } \\
\text { Coating } \\
\text { Product } \\
\text { Name }\end{array}$ & $\begin{array}{l}\text { Applicable } \\
\text { Media }\end{array}$ & $\begin{array}{l}\text { Application } \\
\text { Method }\end{array}$ & $\begin{array}{l}\text { Removal } \\
\text { Method }\end{array}$ & $\begin{array}{l}\text { Purpose of } \\
\text { Coating }\end{array}$ & $\begin{array}{l}\text { Loose Surface } \\
\text { Contaminants } \\
\text { Removed }\end{array}$ \\
\hline $\begin{array}{l}\text { Spraylat } \\
\text { Preservation } \\
\text { System }\end{array}$ & $\begin{array}{l}\text { Metal } \\
\text { Equipment } \\
\text { Plastic } \\
\text { Porcelain } \\
\text { Paint }\end{array}$ & Spray & $\begin{array}{l}\text { Removed in } \\
\text { whole strips }\end{array}$ & $\begin{array}{l}\text { Protection of } \\
\text { equipment (e.g., } \\
\text { nuclear } \\
\text { powerhouse) during } \\
\text { shipment and } \\
\text { storage. }\end{array}$ & $-\cdots$ \\
\hline 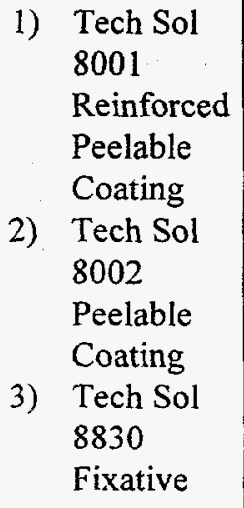 & $\begin{array}{l}\text { Metal } \\
\text { Concrete } \\
\text { Transite } \\
\text { Equipment }\end{array}$ & $\begin{array}{l}\text { Spray } \\
\text { Brush } \\
\text { Roller }\end{array}$ & $\begin{array}{l}\text { Removed in } \\
\text { whole strips }\end{array}$ & $\begin{array}{l}\text { Decontaminate } \\
\text { Fixative } \\
\text { Protective barrier }\end{array}$ & $\begin{array}{l}\text { Alpha/Beta Emitters } \\
\text { Metal Oxides }\end{array}$ \\
\hline $\begin{array}{l}\text { Protexo Cote } \\
\text { V-12 White }\end{array}$ & $\begin{array}{l}\text { Metal } \\
\text { Concrete } \\
\text { Equipment } \\
\text { Glass }\end{array}$ & $\begin{array}{l}\text { Spray } \\
\text { Brush } \\
\text { Roller } \\
\text { Dip }\end{array}$ & $\begin{array}{l}\text { Removed in } \\
\text { whole strips }\end{array}$ & Protective barrier & -...- \\
\hline 1331 Nanapeel & $\begin{array}{l}\text { Metal } \\
\text { Concrete } \\
\text { Equipment }\end{array}$ & Spray & $\begin{array}{l}\text { Removed in } \\
\text { whole strips }\end{array}$ & Protective barrier & $\cdots$ \\
\hline $\begin{array}{l}\text { Carboline } \\
1146 \text { ALARA } \\
\text { Cavity Decon } \\
\text { or Strippable }\end{array}$ & $\begin{array}{l}\text { Metal } \\
\text { Concrete } \\
\text { Transite } \\
\text { Equipment } \\
\text { Plastic }\end{array}$ & $\begin{array}{l}\text { Spray } \\
\text { Brush } \\
\text { Roller } \\
\text { Squeeqee/ } \\
\text { Pour }\end{array}$ & $\begin{array}{l}\text { Removed in } \\
\text { whole strips }\end{array}$ & $\begin{array}{l}\text { Decontaminate } \\
\text { Fixative } \\
\text { Protective barrier } \\
\text { Removes paint if } \\
\text { coating is loose }\end{array}$ & $\begin{array}{l}\text { Water soluble and } \\
\text { transit radionuclides } \\
\text { and metals } \\
\text { Organics }\end{array}$ \\
\hline
\end{tabular}




\section{STRIPPABLE COATING PRODUCT INFORMATION}

Table B.3. Miscellaneous Information

\begin{tabular}{|c|c|c|c|c|}
\hline $\begin{array}{l}\text { Strippable Coating } \\
\text { Product Name }\end{array}$ & $\begin{array}{l}\text { Respirator } \\
\text { Required } \\
\text { for Use? }\end{array}$ & $\begin{array}{l}\text { Temperature } \\
\text { Range for } \\
\text { Use }\left({ }^{\circ} \mathrm{F}\right)\end{array}$ & $\begin{array}{c}\text { Scuff and } \\
\text { Abrasions } \\
\text { Rating (1-5) }\end{array}$ & Additional Information \\
\hline $\begin{array}{l}33701 \text { Blue/White } \\
\text { Peelable }\end{array}$ & No & $32-118$ & 5 & ---- \\
\hline Proxpeel & No & $65-77$ & $-\cdots$ & --- \\
\hline $\begin{array}{l}\text { Stripcoat TLC } \\
\text { Stripcoat TLC free }\end{array}$ & Yes & $45-100$ & 3 & Exclusive product of Bartlett. \\
\hline Dip Seal & No & --- & 5 & $\begin{array}{l}\text { Dip Seal is a non-toxic, strippable, } \\
\text { thermal plastic coating that has been used } \\
\text { in the machine tool, aerospace, and } \\
\text { woodworking industries for the past } 48 \\
\text { years. Most recently it has gained new } \\
\text { use in the bottling industries... }\end{array}$ \\
\hline $\begin{array}{l}\text { Peel Coat System } \\
\text { (200 Top Coat } / 912 \\
\text { Base) }\end{array}$ & No & $\begin{array}{l}\text { less than } \\
100\end{array}$ & 4 & $\begin{array}{l}\text { Peel Coat is a strippable protective } \\
\text { coating for the cutting tool industry. It is } \\
\text { comprised of a two part system: a base } \\
\text { coat and a top coat. }\end{array}$ \\
\hline G-116 & Yes & $40-110$ & 4 & ----- \\
\hline J.D.L. \#GP-RDM & Yes & above 50 & 3 & ---- \\
\hline InstaCote ${ }^{\circledR}-\mathrm{ML}$ & $\begin{array}{l}\text { Yes } \\
\text { (supplied } \\
\text { air) }\end{array}$ & above 45 & 4 & $\begin{array}{l}\text { Contains isocyanates. Has shielding } \\
\text { properties. Is water impervious. Has gone } \\
\text { through irradiation testing at the } \\
\text { University of Michigan. Tested for } \\
\text { various ASTMs. Authorized for burial. } \\
\text { Cures to touch in } 2-5 \text { seconds (can be } \\
\text { walked on almost immediately). }\end{array}$ \\
\hline Pentek 603/604 & No & at least 55 & 2 & ---- \\
\hline $\begin{array}{l}\text { Spraylat } \\
\text { Preservation System }\end{array}$ & No & above 45 & ---- & $\begin{array}{l}\text { The top coat applied over a wet base coat } \\
\text { dries in two hours to a rain resistant } \\
\text { coating. Used as a multicoat system. Two } \\
\text { base coats are used, each a different color } \\
\text { to provide a color contrast. A topcoat is } \\
\text { applied over the base coats and finally a } \\
\text { coverlac which is used to seal any } \\
\text { pinholes or tears in the topcoat. }\end{array}$ \\
\hline
\end{tabular}


Table B.3. Miscellaneous Information (Continued)

\begin{tabular}{|c|c|c|c|c|}
\hline $\begin{array}{c}\text { Strippable } \\
\text { Coating Product } \\
\text { Name }\end{array}$ & $\begin{array}{l}\text { Respirator } \\
\text { Required } \\
\text { for Use? }\end{array}$ & $\begin{array}{l}\text { Temperature } \\
\text { Range for } \\
\text { Use }\left({ }^{\circ} \mathrm{F}\right)\end{array}$ & $\begin{array}{c}\text { Scuff and } \\
\text { Abrasions } \\
\text { Rating (1-5) }\end{array}$ & Additional Information \\
\hline $\begin{array}{l}\text { Spraylat } \\
\text { Preservation } \\
\text { System }\end{array}$ & No & above 45 & --- & $\begin{array}{l}\text { The top coat applied over a wet base coat } \\
\text { dries in two hours to a rain resistant coating. } \\
\text { Used as a multicoat system. Two base coats } \\
\text { are used, each a different color to provide a } \\
\text { color contrast. A topcoat is applied over the } \\
\text { base coats and finally a coverlac which is } \\
\text { used to seal any pinholes or tears in the } \\
\text { topcoat. }\end{array}$ \\
\hline $\begin{array}{l}\text { 1) Tech Sol } \\
8001 \\
\text { Reinforced } \\
\text { Peelable } \\
\text { Coating } \\
\text { 2) Tech Sol } \\
8002 \text { Peelable } \\
\text { Coating } \\
\text { 3) Tech Sol } \\
\text { 8830 Fixative }\end{array}$ & $\begin{array}{l}\text { Yes } \\
\text { (for Tech } \\
\text { Sol } 8830 \\
\text { only) }\end{array}$ & $50-100$ & 5 & ---- \\
\hline $\begin{array}{l}\text { Protexo Cote V- } \\
12 \text { White }\end{array}$ & Yes & ambient & 4 & --- \\
\hline 1331 Nanapeel & Yes & above 50 & 5 & $\begin{array}{l}\text { This strippable coating has excellent Fire } \\
\text { Retardant/Flame Spread Index. This } \\
\text { product is also available in Water Borne. } \\
\text { Also available in both clear and pigmented. }\end{array}$ \\
\hline $\begin{array}{l}\text { Carboline } 1146 \\
\text { ALARA Cavity } \\
\text { Decon or } \\
\text { Strippable }\end{array}$ & No & $35-100$ & 5 & $\begin{array}{l}\text { Available in two forms: yellow for cavity } \\
\text { decontamination and blue for general } \\
\text { purposes. The cavity decon ALARA meets } \\
\text { certification requirements. }\end{array}$ \\
\hline
\end{tabular}




\section{APPENDIX C}

\section{DOE D\&D SURVEY FORM}

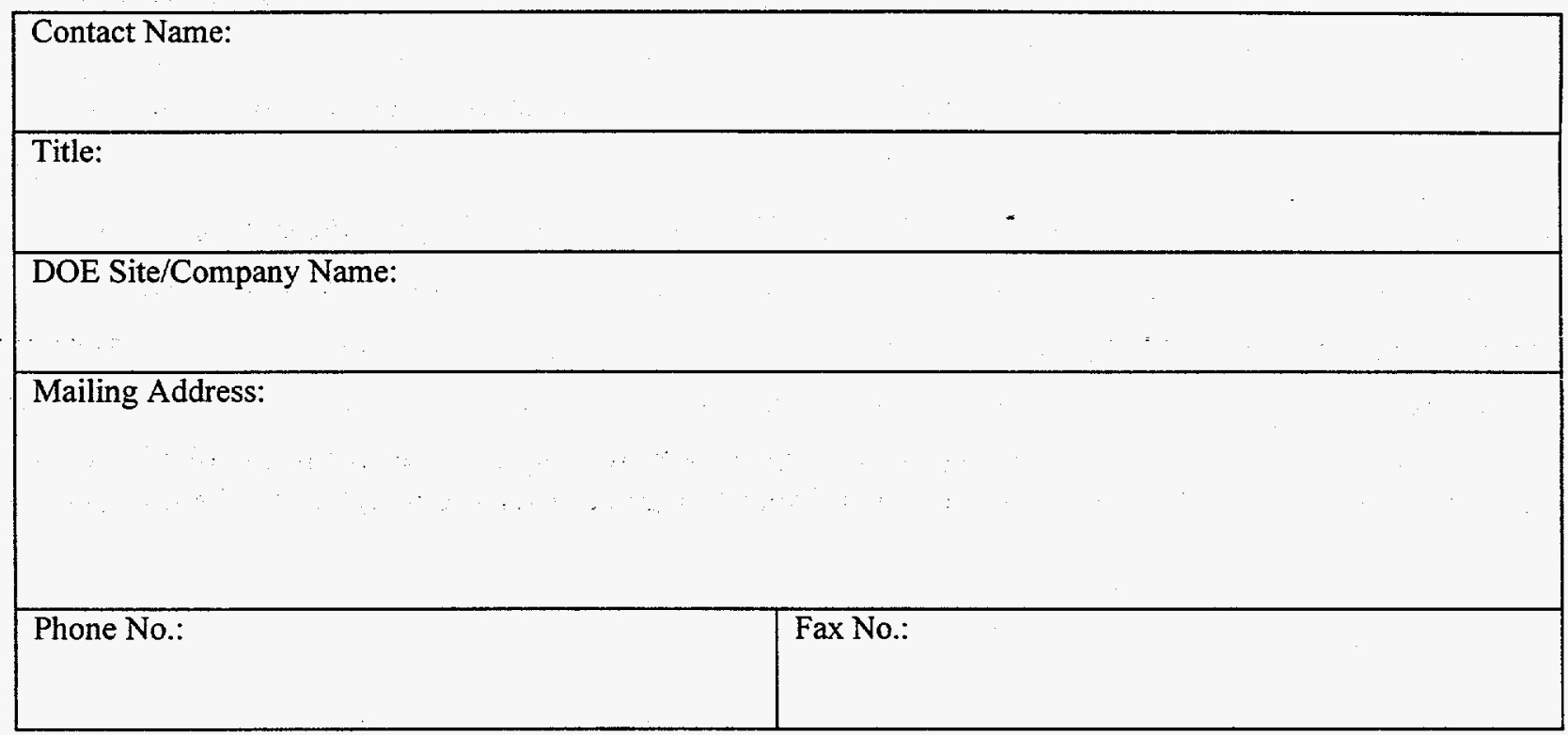

\section{Please fill out the above table as much as possible.}

1. Have you ever used a strippable coating project for decontamination and/or decommissioning?

a. Yes, continue with Question 2 (do not miss 13 and 14)

b. No, skip to Question 11

2. What strippable coating product or products have you tried?

Product 1)

Product 2)

Product 3)

For multiple products please check the boxes for the representative product number.

[ ] (Product 1) [ ] (Product 2) [ ] (Product 3)

3. What type of material did you use the strippable coating on? 

a. [] [] [] Stainless steel
b. [] [] [ ] Carbon steel
c. [] [] [] Concrete
d. [ ] [ ] [ ] Transite
e. [] [ ] [ ] Painted metals or sufaces
f. [] [] [ ] Other:

4. Where did you use the strippable coating on?
a. [] [] [ ] Floors
b. [ ] [ ] [ ] Walls
c. [] [] [] Ceilings
d. [ ] [ ] [ ] Equipment
e. [] [] [] Other:

5. What method was used to apply the strippable coating?
a. [] [] [] Sprayed
b. [] [] [] Brushed
c. [] [] [] Rolled
d. [] [] [] Other:

6. What method was used to remove the strippable coating?
a. [] [] [ ] Removed in whole or large strips.
b. [ ] [] [ ] Broke off in small, brittle pieces, and vacuumed off
c. [] [] [ ] Other:

7. How long did you leave the strippable coating on?
a. [] [] [ ] Followed the manufacturer's guidelines
b. [ ] [ ] [ ] For several days over the manufacturer's guidelines
c. [] [ ] [ ] For several weeks
d. [] [] [] For months

8. What was the purpose of using the strippable coating?
a. [] [ ] [ ] Remove loose radiological contamination from surface 
b. [ ] [ ] [ ] Remove loose metal contamination from surface

c. [] [] [] Fix a contaminant to the surface to prevent the spread of contaminant

d. [ ] [ ] [ ] Prevention of airborne radioactive contamination

e. [ ] [ ] [ ] Prevent personnel contamination or minimize the use of protective clothing

f. [ ] [ ] [ ] Act as a barrier against possible contamination

g. [ ] [ ] [ ] Remove paint from surface

h. [ ] [ ] [ ] Other:

9. What is your opinion about the performance of the strippable coating product(s) you have used? What did you like, or not like, about the product(s)?

10. Were there strippable coating products that you considered but decided not to try? If so, why?

11. For what purpose (or previously untried purpose) would you consider using strippable coatings?
a. Remove loose radiological contamination from surface
b. Remove loose metal contamination from surface
c. Fix a contaminant to the surface
d. Act as a barrier against possible contamination
e. Remove paint from surface
f. Other:

12. On what type of material?
a. Stainless steel
b. Carbon steel
c. Other metal:
d. Concrete
e. Other:

13. Where would you consider using strippable coatings?
a. Walls
b. Floors 

c. Ceilings
d. Equipment
e. Other:

14. For your site to use strippable coatings in your D\&D effort, what performance criteria do you consider important for the strippable coating product to have to meet?

Examples:

Product must be able to be applied in 90 degree heat with 90 percent humidity.

Product must be strong enough for people to walk on for several days.

Product must be able to be left on a wall for 30 days or more.

Product must be strong and pliable so that it can be removed easily.

Product cannot contain/use organic solvents.

Product cannot generate mixed waste.

Please list as many of the performance criteria that are important to your site as you can. These will be compiled and used to develop the performance-based criteria used in the laboratory-scale testing of several strippable coating products.

15. Please add any additional comments concerning strippable coatings or information you would like to see tested by HCET during the laboratory-scale testing of strippable coatings:

Thank you very much for completing this survey. Your assistance is very much appreciated and the information you have supplied us will be used in the design of the laboratory-scale testing of strippable coatings. Feel free to call. 


\section{APPENDIX D}

\section{DOE D\&D SURVEY RESULTS}

Table D.1. DOE Contact Information

\begin{tabular}{|c|c|c|c|}
\hline DOE Site/Company Name & $\begin{array}{c}\text { Contact Name and } \\
\text { Title }\end{array}$ & Phone Number & Fax Number \\
\hline Fluor Daniel Fernald & $\begin{array}{l}\text { Jeff Bowers } \\
\text { Project Engineer }\end{array}$ & (513) 648-5155 & (513) 648-5234 \\
\hline $\begin{array}{l}\text { Idaho/Lockheed Martin Idaho } \\
\text { Technologies Company }\end{array}$ & $\begin{array}{l}\text { Richard H. Maservey } \\
\text { Consulting } \\
\text { Engineer/Scientist }\end{array}$ & (208) 526-1834 & (208) $526-5142$ \\
\hline Los Alamos National Laboratory & $\begin{array}{l}\text { John Elliott } \\
\text { Lead Radiological } \\
\text { Control Technician, } \\
\text { TA } 21 \text { D\&D Project }\end{array}$ & ----- & ---- \\
\hline $\begin{array}{l}\text { Y-12, Oak Ridge } \\
\text { MK-Ferguson of Oak Ridge }\end{array}$ & $\begin{array}{l}\text { Michael H. Waldroop } \\
\text { Construction } \\
\text { Superintendent }\end{array}$ & (423) 576-4134 & (423) $574-3829$ \\
\hline DOE Nevada Operations & $\begin{array}{l}\text { Clayton W. Barrow } \\
\text { D\&D Task Manager }\end{array}$ & (702) $295-7960$ & (702) $295-1113$ \\
\hline $\begin{array}{l}\text { Rocky Flats Environmental Technology } \\
\text { Site } \\
\text { RFFO }\end{array}$ & $\begin{array}{l}\text { Gary N. Huffman } \\
\text { Technical Program } \\
\text { Officer }\end{array}$ & (303) 966-7490 & (303) $966-6713$ \\
\hline $\begin{array}{l}\text { Savannah River Site } \\
\text { Westinghouse Savannah River Co. }\end{array}$ & $\begin{array}{l}\text { Cecil May } \\
\text { Principal Engineer }\end{array}$ & (803) $725-5813$ & (803) $725-4704$ \\
\hline
\end{tabular}




\section{DOE SURVEY RESULTS}

Table D.2. Current Uses of Strippable Coatings

\begin{tabular}{|c|c|c|c|c|}
\hline $\begin{array}{c}\text { DOE Site/Company } \\
\text { Name }\end{array}$ & $\begin{array}{c}\text { Coating } \\
\text { Currently Using }\end{array}$ & $\begin{array}{l}\text { Substrate } \\
\text { Material }\end{array}$ & Substrate & Purpose of Use \\
\hline Fluor Daniel Fernald & Bartlett Stripcoat & Concrete & Floors & $\begin{array}{l}\text { Protective barrier against } \\
\text { contamination }\end{array}$ \\
\hline $\begin{array}{l}\text { Idaho/Lockheed Martin } \\
\text { Idaho Technologies } \\
\text { Company }\end{array}$ & None used & --.-- & --- & ---- \\
\hline $\begin{array}{l}\text { Los Alamos National } \\
\text { Laboratory }\end{array}$ & $\begin{array}{l}\text { ALARA Cavity } \\
\text { Decon } \\
\text { Sensor Coat }\end{array}$ & $\begin{array}{l}\text { Stainless and } \\
\text { carbon steel } \\
\text { Concrete } \\
\text { Painted metal or } \\
\text { surfaces }\end{array}$ & $\begin{array}{l}\text { Floors } \\
\text { Walls } \\
\text { Ceilings } \\
\text { Equipment }\end{array}$ & $\begin{array}{l}\text { Remove loose radiological } \\
\text { and metal contamination. } \\
\text { Fixative. } \\
\text { Prevention of airborne } \\
\text { contamination. }\end{array}$ \\
\hline $\begin{array}{l}\text { Y-12, Oak Ridge } \\
\text { MK-Ferguson of Oak } \\
\text { Ridge }\end{array}$ & $\begin{array}{l}\text { Peel Away } \\
\# 1,2 \text {, and } 7\end{array}$ & $\begin{array}{l}\text { Carbon steel } \\
\text { Concrete } \\
\text { Painted metals or } \\
\text { surfaces } \\
\text { CMU (block or } \\
\text { brick) }\end{array}$ & $\begin{array}{l}\text { Floors } \\
\text { Walls } \\
\text { Ceilings } \\
\text { Equipment }\end{array}$ & $\begin{array}{l}\text { Lead and asbestos paint } \\
\text { removal }\end{array}$ \\
\hline DOE Nevada Operations & $\begin{array}{l}\text { Stripcoat TLC } \\
\text { free }\end{array}$ & $\begin{array}{l}\text { Concrete } \\
\text { Galvanized steel }\end{array}$ & Floors & $\begin{array}{l}\text { Remove loose radiological } \\
\text { contamination. }\end{array}$ \\
\hline $\begin{array}{l}\text { Rocky Flats } \\
\text { Environmental } \\
\text { Technology Site } \\
\text { RFFO }\end{array}$ & $\begin{array}{l}\text { ALARA } 1146 \\
\text { Stripcoat TLC }\end{array}$ & $\begin{array}{l}\text { Stainless and } \\
\text { carbon steel } \\
\text { Concrete } \\
\text { Painted metal or } \\
\text { surfaces }\end{array}$ & $\begin{array}{l}\text { Floors } \\
\text { Walls } \\
\text { Ceilings } \\
\text { Equipment }\end{array}$ & $\begin{array}{l}\text { Remove loose radiological } \\
\text { contamination. } \\
\text { Fixative } \\
\text { Prevention of airborne } \\
\text { radioactive contamination. } \\
\text { Act as a barrier against } \\
\text { possible contamination. }\end{array}$ \\
\hline $\begin{array}{l}\text { Savannah River Site } \\
\text { Westinghouse Savannah } \\
\text { River Co. }\end{array}$ & $\begin{array}{l}\text { Stripcoat TLC } \\
\text { ALARA }\end{array}$ & $\begin{array}{l}\text { Stainless and } \\
\text { carbon steel } \\
\text { Concrete } \\
\text { Painted metals or } \\
\text { surfaces } \\
\text { Electrical wiring } \\
\text { Plastics } \\
\text { Rubber }\end{array}$ & $\begin{array}{l}\text { Walls } \\
\text { Equipment }\end{array}$ & $\begin{array}{l}\text { Remove loose radiological } \\
\text { contamination. } \\
\text { Fixative } \\
\text { Prevention of airborne } \\
\text { radioactive contamination. } \\
\text { Prevent personnel } \\
\text { contamination to minimize } \\
\text { PPE. } \\
\text { Act as a barrier against } \\
\text { possible contamination }\end{array}$ \\
\hline
\end{tabular}

(1) Developed at LANL, not currently commercially available. This coating changes color to indicate the presence of contamination. 


\section{DOE SURVEY RESULTS}

Table D.3. Performance Criteria

\begin{tabular}{|c|c|c|}
\hline DOE Site/Company Name & Performance Criteria Identified & Additional Information Requested \\
\hline Fluor Daniel Fernald & $\begin{array}{l}\text { Product must be able to be applied } \\
\text { between } 20 \text { and } 80 \text { degree, } \mathrm{F} \text {. } \\
\text { Product must be strong and pliable. }\end{array}$ & -- \\
\hline $\begin{array}{l}\text { Idaho/Lockheed Martin } \\
\text { Idaho Technologies } \\
\text { Company }\end{array}$ & $\begin{array}{l}\text { Must be sprayed or painted on. } \\
\text { No organic solvents. } \\
\text { Not create a mixed waste. } \\
\text { Strong enough to come off in } \\
\text { reasonably sized sheets. } \\
\text { Easy to apply (no expensive or } \\
\text { hard to obtain equipment). } \\
\text { Should set at temperature down to } \\
\text { about } 45^{\circ} \mathrm{F} \text {. } \\
\text { Must remain stable to contain the } \\
\text { contamination. } \\
\text { Should be able to leave it on for at } \\
\text { least } 30 \text { days. }\end{array}$ & $\begin{array}{l}\text { Test on smooth and rough concrete (with } \\
\text { some cracks). } \\
\text { Get good photos during removal. } \\
\text { Be careful to get good (and comparable) } \\
\text { data on decon factors. } \\
\text { Compile cost per } \mathrm{ft}^{2} \text { of application and } \\
\text { removal. } \\
\text { Test after } 4 \text { hours and after } 30 \text { days. }\end{array}$ \\
\hline $\begin{array}{l}\text { Los Alamos National } \\
\text { Laboratory }\end{array}$ & $\begin{array}{l}\text { Ease of use. } \\
\text { Performance-decon level. } \\
\text { Ease of application. } \\
\text { Ease of removal. } \\
\text { Ability to penetrate a crust to fix } \\
\text { (encapsulate) contamination } \\
\text { below. } \\
\text { Cannot generate a mixed waste. }\end{array}$ & ---- \\
\hline $\begin{array}{l}\text { Y-12, Oak Ridge } \\
\text { MK-Ferguson of Oak Ridge }\end{array}$ & $\begin{array}{l}\text { Product must be able to be applied } \\
\text { in } 90 \text { degree heat with } 90 \text { percent } \\
\text { humidity. } \\
\text { Product must be strong and pliable } \\
\text { so that it can be removed easily. } \\
\text { Product cannot contain/use organic } \\
\text { solvents. } \\
\text { Product cannot generate mixed } \\
\text { waste. }\end{array}$ & $-\ldots-$ \\
\hline
\end{tabular}


Table D.3. Performance Criteria (Continued)

\begin{tabular}{|c|c|c|}
\hline DOE Site/Company Name & Performance Criteria Identified & Additional Information Requested \\
\hline DOE Nevada Operations & $\begin{array}{l}\text { Product must be strong and pliable } \\
\text { so that it can be removed easily. } \\
\text { Product cannot contain/use organic } \\
\text { solvents. } \\
\text { Product cannot generate mixed } \\
\text { waste. } \\
\text { Easy to apply with minimal waste } \\
\text { generation. } \\
\text { Fast cure time. } \\
\text { Ability to reduce airborne activity. }\end{array}$ & $\begin{array}{l}\text { Testing of coatings on various types of metal } \\
\text { surfaces. } \\
\text { Testing of coatings in direct sunlight. }\end{array}$ \\
\hline $\begin{array}{l}\text { Rocky Flats Environmental } \\
\text { Technology Site } \\
\text { RFFO }\end{array}$ & $\begin{array}{l}\text { Product must be strong enough for } \\
\text { people to walk on for several days. } \\
\text { Product must be able to be left on a } \\
\text { wall for } 30 \text { days or more. } \\
\text { Product must be strong and pliable } \\
\text { so that it can be removed easily. } \\
\text { Product cannot contain/use organic } \\
\text { solvents. } \\
\text { Product cannot generate mixed } \\
\text { waste. }\end{array}$ & $\begin{array}{l}\text { Decontamination factors (DF) for removal of } \\
\text { smearable contamination. } \\
\text { Ease of application/removal from various } \\
\text { substrates. } \\
\text { Capable of having multiple coats removed as } \\
\text { one ("sandwich"). }\end{array}$ \\
\hline $\begin{array}{l}\text { Savannah River Site } \\
\text { Westinghouse Savannah } \\
\text { River Co. }\end{array}$ & $\begin{array}{l}\text { Effect of heat, humidity, direct } \\
\text { sun, and time on the drying and } \\
\text { removal characteristics. } \\
\text { Drying/curing time required before } \\
\text { additional coating ( } 2^{\text {nd }} \text { coat) or the } \\
\text { intended use. } \\
\text { Ease/cost of application and } \\
\text { removal. } \\
\text { Durability of coating during use. }\end{array}$ & $\begin{array}{l}\text { What is the characterization of the substrate } \\
\text { being decontaminated? Both in terms of } \\
\text { isotopes, chemical form (metal, high-fired } \\
\text { oxide, etc.), and contamination level. } \\
\text { What is waste characterization of the } \\
\text { resultant stripped coating? } \\
\text { What is the cost of the application? (Detail } \\
\text { desired to assess whether procedures, rad } \\
\text { protection, etc. were included in unit cost.) } \\
\text { Please include InstaCote MLl and ML2 as } \\
\text { test coatings. }\end{array}$ \\
\hline
\end{tabular}

